\title{
EFFECT OF N, K AND N APPLICATION TIME ON YIELD AND UPTAKE OF WHEAT PLANTS AT NORTH DELTA \\ Faizy, S. E. A. ${ }^{1}$; M. M. RezK'하 E. A. E. Gazia ${ }^{2}$ and M. M. A. Amer ${ }^{2}$ \\ ${ }^{1}$ Dept. of soil Sci. Fac. of Agric. Kafr El-Sheikh Univ. \\ ${ }^{2}$ Soil, Water and Environment Res. Instit. A.R.C.
}

\begin{abstract}
A field experiment was carried out during the two successive water seasons of 2002/2003 and 2003/2004. The objective of this works was to study the role of $\mathrm{N}$ application at tillering stage and effect of $\mathrm{K}$ on wheat (Triticum aestivum L.) yield, uptake of $\mathrm{N}, \mathrm{P}, \mathrm{K}$ and $\mathrm{N}$-recovery. The obtained results could be summarized as follows:

Grain and straw yields were highly significantly increased with increasing $\mathrm{N}$ level up to $120 \mathrm{~kg} \mathrm{~N} / \mathrm{fed}$. ( $\mathrm{fed}=4200 \mathrm{~m}^{2}$ ) of the two studied wheat varieties. The highest mean values were 21.91 and 30.0 ardab grain/fed, (ardab=150 kg) and 5.19 and 6.0 tons straw/fed. for Giza 168 and Sids7, respectively.

Applications of $\mathrm{N}$ at tillering stage in the presence of $\mathrm{K}$ have a high significant effect on grain and straw yields, of the two wheat varieties.

Application of $\mathrm{N}$ by the rates of $24,60,18$ and $18 \mathrm{~kg} / \mathrm{fed}$. at planting, tillering, booting and milk stages dry weight of wheat plants at maturity stage recorded the highest-mean value by about 172.2 \%and $198.3 \%$ for Giza 168 and Sids7, respectively.

Applying $\mathrm{K}$ increased dry matter at tillering stage, booting and maturity stage for Giza 168 and Sids7. However Sids7 pronounced Giza 168.

$\mathrm{N}, \mathrm{P}$ and K-uptake by wheat plants was increased for the two studied varieties by $\mathrm{N}$ application up to $120 \mathrm{~kg} \mathrm{~N} / \mathrm{fed}$ and applying $\mathrm{K}$. Uptake of $\mathrm{N}, \mathrm{P}$ and $\mathrm{K}$ by Sids7 surpassed Giza 168

Increasing N from 75 to $120 \mathrm{~kg} / \mathrm{fed}$ increased $\mathrm{N}$-recovery and recorded the highest value at tillering stage $>$ booting $>$ maturity stage of the two wheat varieties.

Applying $\mathrm{N}$ at tillering stage for Sids7, recorded high $\mathrm{N}$-recovery which surpassed Giza 168 by about $18.69 \%$.

Applying $\mathrm{K}$ increased nitrogen use efficiency (NUE) by about $18.21 \%$ and $19.24 \%$ for Giza 168 and Sids7, respectively.

Increasing $\mathrm{N}$ from 75 to $120 \mathrm{~kg} /$ fed increased the crude protein content in grains by about $12.47 \%$ and $16.2 \%$ and applying $\mathrm{K}$ increased them by 5.48 and $7.06 \%$ for Giza 168 and Sids7, respectively.

Keywords: Wheat (Triticum aestivum L.), Nitrogen, potassium, tillering stage, time application, NPK Uptake, NUE, N-recovery and crude protein content\%.
\end{abstract}

\section{INTRODUCTION}

Wheat (Triticum aestivum L.) is strategic crop because of its indispensable part of food diet. Wheat cultivation is widely scattered all over Egypt. Reducing the gap between production and consumption of wheat is a national policy in Egypt. Wheat is very sensitive to insufficient $\mathrm{N}$. Application of $\mathrm{N}$ for wheat as one dose was usually practiced in the past. Recently, Forestar (1973) found that, the grain and straw yields of wheat increased when the $\mathrm{N}$ fertilizer was splited into two or three doses. Moreover, the addition of four $\mathrm{N}$ doses gave higher yield than $3 \mathrm{~N}$ doses (Rahman et al 2002). Also, Faizy et al. (1986) found that, the grain yield of wheat was higher when the nitrogen was split into 4 doses than when split into 3 or 2 doses. 
Nitrogen use efficiency has been considerably improved by splitting $\mathrm{N}$ dressing in winter wheat (Faizy et al.1986 and Mengel and Kirkby 2001).

Potassium is necessary for plant growth, where it plays an integral part. Enzymes are involved in many important plant physiological processes, and over 80 plant enzymes require $\mathrm{K}$ for their activation. $\mathrm{K}$-fertilization has a role in decreasing certain plant diseases and improving quality. Thus the intensive agriculture reduced the level of available $\mathrm{K}$ in the soil; nowadays insufficient soil $\mathrm{K}$ is usually corrected by adding $\mathrm{K}$ fertilizer which has a beneficial influence on the development of endosperm cells and hence on the single grain weight of cereals. Genaidy and Hegazy (2001) indicated that 24 $\mathrm{Kg} \mathrm{K}_{2} \mathrm{O} /$ fed as $\mathrm{K}_{2} \mathrm{SO}_{4}$ fertilizer increased the yield of wheat by $20.76 \%$.

Amer (2009) pointed out that $\mathrm{N}$-uptake and recovery by wheat yield was increased with application of nitrogen and potassium, nitrogen use efficiency (NUE) by wheat yield was decreased with increasing application of nitrogen but improved by addition of $50 \mathrm{~kg} \mathrm{~K}_{2} \mathrm{Ofed}^{-1}$

Therefore, the main target of this investigation is to study the effect of $\mathrm{N}$ level at tillering stage and $\mathrm{K}$ fertilization on the yield of two wheat varieties Giza 168 and Sids7 as well as N, P and K uptake by wheat plants.

\section{MATERIALS AND METHODS}

Two field experiments were carried out at the Experimental Farm, Faculty of Agric., Kafr El Sheikh, Tanta Univ. ( $6 \mathrm{~m}$ altitude, $31^{\circ} 07$ - latitude and $30^{\circ}$ 52- longitude ) during two successive seasons of 2002/2003 and 2003/2004 with two wheat varieties Giza 168 and Sids7, to study the effect of two $\mathrm{N}$ levels, two levels of $\mathrm{K}$ (with and without $50 \mathrm{~kg} / \mathrm{fed}$ ), timing of $\mathrm{N}$ application at different physiological stages (planting, tillering, booting and milk) on grain and straw yield, dry weight after tillering, booting and maturity stage, as well as $\mathrm{N}, \mathrm{P}$ and $\mathrm{K}$ uptake by wheat plants.

The experiment was conducted in a split - split - split plot design, with four replicates. The main plots were randomly assigned to timing of doses of N, sub plot were assigned to $\mathrm{N}$ level (75 and $120 \mathrm{~kg} / \mathrm{fed}$.), sub - sub plot to $\mathrm{K}$ level and the sub-sub-sub plot to wheat variety. The area of each plot was 3 X 3.5 square meter $(1 / 400)$ fed. The $\mathrm{N}$ was applied as urea (46\% $\mathrm{N})$ in four doses. The first dose was divided into two levels $15,24, \mathrm{Kg} \mathrm{N} / \mathrm{fed}$ and broadcasted with $22 \mathrm{Kg} \mathrm{P}_{2} \mathrm{O}_{5}$ / fed. with $50 \mathrm{Kg} \mathrm{K} 2 \mathrm{O} / \mathrm{fed}$. , as potassium sulphate $\left(48 \% \mathrm{~K}_{2} \mathrm{O}\right)$ at sowing. The second dose of nitrogen was applied at the first irrigation with level: $0,20,30,40,50,60 \mathrm{Kg} \mathrm{N} /$ fed and represented as: $D_{0}, D_{1}, D_{2}, D_{3}, D_{4}, D_{5}$ and $D_{6}$. The rest of $N$ was splited equally between booting and milk stages Table (1).

Soil samples from the surface layer (0-15) and (15-30) were taken from the experimental sites before planting in two seasons and prepared for physical and chemical analysis. The soil characteristics were presented in Table 2. Also, plant samples were taken randomly at age 45 and 90 day to estimate the wheat yield and dry weight.

Soil samples were air-dried crushed and passed through a $2.0 \mathrm{~mm}$ sieve for the chemical analysis, according to Jackson (1967). Cation exchange capacity (CEC): as described by Gohar (1954). Available P 
Faizy, S. E. A. et al.

according to Olsen et al (1954). and K according to Page (1982). Mechanical analysis was determined according to Piper (1950).Protein concentration (\%): was calculated from total $\mathrm{N}$ percent in grain yield multiplied by 6.25 according (A. O. A. C. 1980).

Data were analyzed statistically according to procedures outlined by Cochran and Cox (1960).

Table (1). Layout of the Experiment:

\begin{tabular}{|c|c|c|c|c|c|c|c|}
\hline \multicolumn{8}{|c|}{ TREATMENTS (Kg / fed.) } \\
\hline \multirow{3}{*}{ D } & \multirow{3}{*}{ N Level } & \multirow{2}{*}{\multicolumn{4}{|c|}{$\begin{array}{l}\text { Different doses of } \mathrm{N} \text { at physiological growth } \\
\text { stages }\end{array}$}} & \multirow{3}{*}{$\frac{P}{\mathbf{P}_{2} \mathbf{O}_{5}}$} & \multirow{3}{*}{$\frac{\mathrm{K}}{\mathrm{K}_{2} \mathrm{O}}$} \\
\hline & & & & & & & \\
\hline & & Planting & Tillering & Booting & Milk & & \\
\hline D0 & 0 & 0 & 0 & 0 & 0 & 0 & 0 \\
\hline D1 & 75 & 15 & 0 & 30 & 30 & 22 & $\begin{array}{c}0 \\
50\end{array}$ \\
\hline $\mathrm{D} 2$ & 75 & 15 & 20 & 20 & 20 & 22 & $\begin{array}{l}0 \\
50\end{array}$ \\
\hline D3 & 75 & 15 & 30 & 15 & 15 & 22 & $\begin{array}{c}0 \\
50\end{array}$ \\
\hline D4 & 75 & 15 & 40 & 10 & 10 & 22 & $\begin{array}{c}0 \\
50\end{array}$ \\
\hline D5 & 75 & 15 & 50 & 5 & 5 & 22 & $\begin{array}{c}0 \\
50\end{array}$ \\
\hline D6 & 75 & 15 & 60 & 0 & 0 & 22 & $\begin{array}{c}0 \\
50\end{array}$ \\
\hline D1 & 120 & 24 & 0 & 48 & 48 & 22 & $\begin{array}{c}0 \\
50\end{array}$ \\
\hline D2 & 120 & 24 & 20 & 38 & 38 & 22 & $\begin{array}{c}0 \\
50\end{array}$ \\
\hline D3 & 120 & 24 & 30 & 33 & 33 & 22 & $\begin{array}{c}0 \\
50\end{array}$ \\
\hline D4 & 120 & 24 & 40 & 28 & 28 & 22 & $\begin{array}{c}0 \\
50\end{array}$ \\
\hline D5 & 120 & 24 & 50 & 23 & 23 & 22 & $\begin{array}{c}0 \\
50\end{array}$ \\
\hline D6 & 120 & 24 & 60 & 18 & 18 & 22 & $\begin{array}{c}0 \\
50\end{array}$ \\
\hline
\end{tabular}

Table (2). Some chemical and physical properties of soil surface layer (0-15, 15-30) before planting.

\begin{tabular}{|c|c|c|c|c|c|}
\hline \multirow{2}{*}{\multicolumn{2}{|c|}{$\begin{array}{c}\text { Year } \\
\text { Soil depth cm }\end{array}$}} & \multicolumn{2}{|c|}{$2002 / 2003$} & \multicolumn{2}{|c|}{$2003 / 2004$} \\
\hline & & $0-15$ & $15-30$ & $0-15$ & $15-30$ \\
\hline \multicolumn{2}{|c|}{ *Soil pH } & 8.0 & 8.1 & 8.1 & 8.13 \\
\hline \multicolumn{2}{|c|}{ EC dsm-1 } & 2.3 & 3.6 & 2.0 & 2.5 \\
\hline \multicolumn{2}{|c|}{ SAR } & 4 & 7 & 5.2 & 6.8 \\
\hline \multirow{3}{*}{$\begin{array}{c}\text { Available } \\
\text { ppm }\end{array}$} & $\mathbf{N}$ & 32 & 17 & 30 & 18 \\
\hline & $\mathbf{P}$ & 12 & 10 & 11 & 10 \\
\hline & $\mathbf{K}$ & 195 & 150 & 201 & 159 \\
\hline \multicolumn{2}{|c|}{ O.M } & 2.36 & 2.18 & 2.41 & 2.20 \\
\hline \multicolumn{2}{|c|}{ Total carbonate \% } & 3.6 & 3.57 & 3.55 & 3.4 \\
\hline \multicolumn{2}{|c|}{ CEC m.e./100g soil } & 45.2 & 43.1 & 47.1 & 44.6 \\
\hline \multicolumn{2}{|c|}{ Saturation percent } & 93 & 90 & 91 & 89 \\
\hline \multirow{3}{*}{$\begin{array}{l}\text { Particle size } \\
\text { distribution } \%\end{array}$} & Clay & 57.2 & 58.11 & 56.90 & 56.71 \\
\hline & Silt & 32.0 & 31.41 & 30.29 & 30.90 \\
\hline & Sand & 10.8 & 10.48 & 12.81 & 12.39 \\
\hline \multicolumn{2}{|c|}{ Texture grade } & clayey & clayey & clayey & clayey \\
\hline
\end{tabular}

* soil pH : (1: 2.5 soil: water suspension).

${ }^{\star \star} E C$ dsm $^{-1}$ : (soil paste extract) 


\section{RESULTS AND DISCUSSION}

-Grain yield:

Data in Table (3) revealed that time of $\mathrm{N}$ application has a high significant effect on grain yield of the studied varieties. The highest mean values were recorded at $D_{6}(15: 60: 0: 0)(24: 60: 18: 18)$ for both $N_{75}$ and $N_{120}$ These results were supported by El-Desokey et al. (2000) and Warraich et al (2002).

Table (3). Effect of $N, K$ and timing of $N$ application and their interactions on grain and straw wheat yield.

\begin{tabular}{|c|c|c|c|c|c|c|c|c|}
\hline \multirow{2}{*}{\multicolumn{5}{|c|}{\begin{tabular}{rr|} 
Treatment \\
N dose (D)
\end{tabular}}} & \multicolumn{2}{|c|}{ Grain yield ardab/fed } & \multicolumn{2}{|c|}{ Straw yield ton/fed } \\
\hline & & & & & \multirow[t]{2}{*}{2003} & \multirow[t]{2}{*}{2004} & \multirow[t]{2}{*}{2003} & \multirow[t]{2}{*}{2004} \\
\hline D & & & Booting & Milk & & & & \\
\hline$D_{0}$ & 0 & 0 & 0 & 0 & 6.005 & 5.5 & 1.85 & 1.78 \\
\hline$D_{1}$ & 15 & 0 & 30 & 30 & 17.013 & 17.24 & 4.15 & 4.23 \\
\hline$D_{2}$ & 15 & 20 & 20 & 20 & 18.319 & 18.34 & 4.23 & 4.31 \\
\hline$D_{3}$ & 15 & 30 & 15 & 15 & 19.954 & 20.007 & 4.35 & 4.48 \\
\hline $\mathrm{D}_{4}$ & 15 & 40 & 10 & 10 & 20.74 & 20.92 & 4.52 & 4.62 \\
\hline$D_{5}$ & 15 & 50 & 5 & 5 & 21.070 & 21.40 & 4.64 & 4.69 \\
\hline$D_{6}$ & 15 & 60 & 0 & 0 & 20.689 & 21.62 & 4.69 & 4.73 \\
\hline \multicolumn{5}{|c|}{ F. test } & ** & ** & $* *$ & ** \\
\hline \multicolumn{5}{|c|}{ LSD $_{0.05}$} & 0.66 & 0.25 & 0.35 & 0.32 \\
\hline \multicolumn{5}{|c|}{ LSD $_{0.01}$} & 0.90 & 0.34 & 0.48 & 0.44 \\
\hline \multicolumn{9}{|c|}{ N level (N): } \\
\hline \multicolumn{5}{|c|}{$\mathrm{N}_{75}$} & 15.709 & 15.71 & 3.58 & 3.67 \\
\hline \multicolumn{5}{|c|}{$\mathbf{N}_{120}$} & 19.662 & 20.01 & 4.54 & 4.57 \\
\hline \multicolumn{5}{|c|}{ F. test } & ** & $* \star$ & ** & ** \\
\hline \multicolumn{9}{|c|}{ K level $(K)$ : } \\
\hline \multicolumn{5}{|c|}{$\mathrm{K}_{0}$} & 16.696 & 16.75 & 3.87 & 3.95 \\
\hline \multicolumn{5}{|c|}{$\mathrm{K}_{50}$} & 18.676 & 18.97 & 4.25 & 4.29 \\
\hline \multicolumn{5}{|c|}{ F. test } & ** & ** & ** & ** \\
\hline \multicolumn{9}{|c|}{ Variety $(\mathrm{V})$ : } \\
\hline \multicolumn{5}{|c|}{ Sids 7} & 19.51 & 19.59 & 4.32 & 4.37 \\
\hline \multicolumn{5}{|c|}{ Giza 168} & 15.86 & 16.13 & 3.81 & 3.87 \\
\hline \multicolumn{5}{|c|}{ F. test } & ** & ** & ** & $\star \star *$ \\
\hline \multicolumn{9}{|c|}{ Interaction: } \\
\hline \multicolumn{5}{|c|}{$D \times N$} & 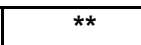 & ** & *夫 & ** \\
\hline \multicolumn{5}{|c|}{$D \times K$} & ** & ** & ** & ** \\
\hline \multicolumn{5}{|c|}{$\mathrm{NxK}$} & * & ** & ** & ** \\
\hline & & $D x$ & & & 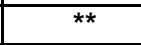 & 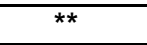 & *夫 & ** \\
\hline & & $\mathrm{Nx}$ & & & $\star \star \star$ & ** & * & * \\
\hline & & $\mathrm{Kx}$ & & & 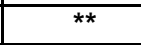 & 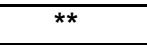 & *夫 & ** \\
\hline & & $\mathrm{DxN}$ & & & 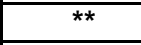 & 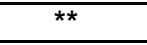 & *夫 & ** \\
\hline & & $\mathrm{D \times N}$ & & & ** & ** & ** & ** \\
\hline & & $\mathrm{DxK}$ & & & 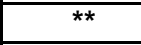 & ** & ** & ** \\
\hline & & V $\times K$ & $x \mathrm{~N}$ & & ** & ** & ** & ** \\
\hline & & $\times \mathrm{Nx}$ & $\mathrm{K} \times \mathrm{V}$ & & ** & ** & ** & ** \\
\hline
\end{tabular}


Faizy, S. E. A. et al.

Data indicated that there were high significant effects on grain yield during the two growing seasons due to the interaction between treatments used in the experiments (Table 3). These results were supported by El Kholy (2000). Data revealed that the highest mean values of grain yield was recorded by $N_{120} P_{22} K_{50}\left(D_{6}\right)$ for Giza 168 and Sids 7 (21.91and 30.0, ardab/fed.), these results were supported by Koreish et al (2004).

-Straw yield:

Table (3) showed that straw yield of the studied wheat varieties were highly significantly increased with increasing $\mathrm{N}$ level up to $120 \mathrm{Kg} / \mathrm{fed}$. The highest mean values were 5.26 and 6.0 tons/fed. for Giza 168 and Sids 7 . These results were supported by El-Sherbieny et al. (1999) and Muhammad (2001).

Data revealed that the straw yields of the studied wheat varieties were highly significantly increased in the presence of potassium. The highest mean value was recorded with Sids 7 (6.0 tons/fed.) These results were supported by Genaidy and Hegazy (2001) and Singh and Pathak (2003).

Data showed that time of $\mathrm{N}$ application has a high significant effect on straw yield of the studied wheat varieties. The highest mean values were recorded at $D_{6}(15: 60: 0: 0)(24: 60: 18: 18)$ for both $N_{75}$ and $N_{120}$. similar results were reported by El Desouqi (2000).

Data indicated that there were high significant effects on straw yield due to the interaction between the applied treatments (Table 3). Data showed that the highest mean values of straw yield was recorded at $N_{120} P_{22} K_{50} D_{5}$ (15:50:5:5) (5.26 tons/fed. and 6.0 tons/fed respectively, for Giza 168 and Sids7). These results were supported by El - Banna (2000) and Wagan et al (2002).

\section{-Dry weight :}

- Dry weight of wheat plants at tillering stage:

Data in Table (4) indicated that the dry weight of wheat plants at tillering stage increased by $60.3 \%$ and $59.10 \%$ for Giza 168 and Sids 7 by increasing $\mathrm{N}$ level to $120 \mathrm{Kg}$ / fed. Similar result was reported by El Yamany (1994).

Data showed that dry weight of the studied wheat varieties increased in the presence of potassium by about $15.93 \%, 18.88 \%$ for Giza 168 and Sids 7 , these results supported by Hegab (1994).

Data of $\mathrm{N}$ time application revealed high effect on dry weight for the two wheat varieties. The highest relative increase was obtained under $D_{6}(60 \mathrm{~kg}$ $\mathrm{N} / \mathrm{feddan}$ at tillering) for all N levels $348.2 \%$ and $335.6 \%$ for Giza 168 and Sids 7,. These results supported by El-Desokey et al (2000) and werraich et al ( 2002$)$.

\section{Dry weight of wheat plants at booting stage:}

Table (4) indicated that the dry weight of wheat plants at booting stage increased $56.15 \%$ and $74.10 \%$ for Giza 168 and Sids 7 by increasing $\mathrm{N}$ level to $120 \mathrm{Kg}$ / fed. These results were supported by Adjetey et al (2001).

Data revealed that dry weight of both wheat varieties Giza 168 and Sids 7 increased in the presence of potassium ( $50 \mathrm{Kg} \mathrm{K}_{2} \mathrm{O} / \mathrm{fed}$.). The mean values increased by about $10.53 \%$ and $33.64 \%$ for Giza 168 and Sids 7 , these results were supported by El Yamany (1994). 
Data showed that time of $\mathrm{N}$ application have a high effect on the two wheat varieties, where the highest relative increase was obtained under $D_{6}$ (348.2 \% and $335.6 \%$ for Giza 168 and Sids 7). These results were supported by warraich et al (2002).

- Dry weight of wheat yield at maturity stage:

Data indicated that the dry weight of wheat yield was increased 22.24 $\%$ and $32.5 \%$ for Giza 168 and Sids 7 by increasing N level to $120 \mathrm{Kg} /$ fed. These results were supported by El-Sherbieny et al (1999) and El-Desouqi (2000).

Data in Table (4) showed that dry weight of wheat yield increased in the presence of potassium $(50 \mathrm{Kg} \mathrm{K} 2 \mathrm{O} /$ fed.) where the mean value increased $9.49 \%$ and $13.19 \%$ for Giza 168 and Sids 7,. These results were supported by Genaidy and Hegazy (2001).

Data revealed that the time of $\mathrm{N}$ application have a high effect on dry weight of the two wheat yield varieties. The highest relative increases were $172.2 \%$ and $198.3 \%$ for Giza 168 and Sids 7 which obtained under $D_{6}(60$ $\mathrm{kg} \mathrm{N} / \mathrm{feddan}$ at tillering). These results were supported by Koreish et al (2004) and Amer (2009)

Table (4). Effect of $\mathrm{N}, \mathrm{K}$ and timing of $\mathrm{N}$ application on the dry weight of wheat plants at different growth stages.

\begin{tabular}{|c|c|c|c|c|c|c|c|}
\hline \multirow{2}{*}{\multicolumn{2}{|c|}{ Treatments }} & \multicolumn{3}{|c|}{ Giza 168} & \multicolumn{3}{|c|}{ Sids 7} \\
\hline & & Tillering & Booting & Maturity & Tillering & Booting & Maturity \\
\hline \multicolumn{2}{|c|}{$\mathbf{N}_{75}$} & 0.456 & 1.791 & 5.26 & 0.528 & 2.059 & 5.84 \\
\hline \multicolumn{2}{|c|}{$\mathbf{N}_{120}$} & 0.731 & 2.797 & 6.43 & 0.842 & 3.586 & 7.74 \\
\hline \multicolumn{2}{|c|}{$\begin{array}{c}\text { Relative } \\
\text { variation \% }\end{array}$} & +60.03 & +56.15 & +22.24 & +59.10 & +74.10 & +32.5 \\
\hline \multicolumn{2}{|c|}{$\mathrm{K}_{\mathrm{o}}$} & 0.549 & 2.179 & 5.58 & 0.625 & 2.524 & 6.37 \\
\hline \multicolumn{2}{|c|}{$\mathrm{K}_{50}$} & 0.637 & 2.408 & 6.11 & 0.743 & 3.121 & 7.21 \\
\hline \multicolumn{2}{|c|}{$\begin{array}{c}\text { Relative } \\
\text { variation \% }\end{array}$} & +15.93 & +10.53 & +9.49 & +18.88 & +23.64 & +13.19 \\
\hline \multicolumn{2}{|c|}{ Do } & 0.173 & 0.593 & 2.03 & 0.1995 & 0.632 & 2.41 \\
\hline \multirow{6}{*}{ 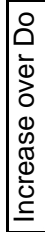 } & D1 & 127.5 & 198.1 & 125.2 & 131.38 & 192.9 & 159.3 \\
\hline & D2 & 177.7 & 243 & 135.7 & 177.7 & 243 & 171.8 \\
\hline & D3 & 224.7 & 275.4 & 155.2 & 225.9 & 339.4 & 179.3 \\
\hline & D4 & 266.5 & 309.9 & 165.7 & 271.1 & 368.6 & 188.8 \\
\hline & D5 & 314.8 & 334.5 & 171.7 & 316.4 & 416.4 & 193.8 \\
\hline & D6 & 348.2 & 357.5 & 172.2 & 335.6 & 441 & 198.3 \\
\hline
\end{tabular}

\section{$\mathrm{N}, \mathrm{P}$ and $\mathrm{K}$ uptake by wheat plant:}

\section{1- Nitrogen uptake:}

Data in Table (5) showed that $\mathrm{N}$-uptake by grains were increased by about $22.89 \%$ and $56.48 \%$ for Giza 168 and Sids7, by increasing N up to $120 \mathrm{~kg} / \mathrm{fed}$. Also N-uptake by grains increased $15.32 \%$ and $25.97 \%$ for the two studied varieties by application of $50 \mathrm{~kg} \mathrm{~K}{ }_{2} \mathrm{O} / \mathrm{fed}$. Similar results were reported by Koch and Mengel (1977). The highest relative increment 486.41 $\%$ and $537.9 \%$ for the two studied varieties were obtained under D6 $(24: 60: 18: 18) \mathrm{kg} \mathrm{N} / \mathrm{fed}$. However $\mathrm{N}$-uptake by grain yield of wheat variety 
Faizy, S. E. A. et al.

Sids7 pronounced N-uptake by grain yield of wheat variety Giza 168. These results were supported by El Sherbieny et al (1999) and Staggenborg et al. (2003)

Data in Table (5) indicated that $\mathrm{N}$-uptake by straw yield increased by about $41.55 \%$ and $33.32 \%$ for the two studied varieties by increasing $\mathrm{N}$ up to $120 \mathrm{~kg} / \mathrm{fed}$. Also N-uptake by straw increased by about $12.96 \%$ and 15.5 $\%$ for the two studied varieties by application $50 \mathrm{~kg} \mathrm{~K} \mathrm{~K}_{2} \mathrm{O} / \mathrm{fed}$ the highest relative increment was $213 \%$ for Giza 168 under D5 (24:50:23:23) kg N/fed and $226 \%$ for Sids7 under D6 (24:60:18:18) kg N/fed. Similar results were reported by Kanani (1996). However $\mathrm{N}$-uptake by straw yield of Sids7 pronounced N-uptake by straw yield of Giza 168 by $9.44 \%$.

Data revealed that $\mathrm{N}$-uptake by wheat plants at tillering stage increased by about $90.4 \%$ and $90.0 \%$ over control $\mathrm{N}_{75}$ for the two studied varieties by increasing $\mathrm{N}$ from 75 to $120 \mathrm{~kg} \mathrm{~N} / \mathrm{fed}$. Also N-uptake increased by about $19.36 \%$ and $21.73 \%$ for the two studied varieties by applying $50 \mathrm{~kg}$ $\mathrm{K}_{2} \mathrm{O} / \mathrm{fed}$. The highest relative increments were $507.24 \%$ and $510.5 \%$ for the two studied varieties under D6 (24:60) kg N/fed. These results supported by Kanani (1996).

Data pointed out that $\mathrm{N}$-uptake at booting stage was increased 38.5 $\%$ and $44.92 \%$ for the two studied varieties by increasing N up to $120 \mathrm{~kg} / \mathrm{fed}$. Also N-uptake at booting stage was increased $12.76 \% 17.75 \%$ for the two studied varieties by applying $50 \mathrm{~kg} \mathrm{~K} \mathrm{~K}_{2} \mathrm{O} / \mathrm{fed}$. The highest relative increment $470.88 \%$ and $510.5 \%$ for the two studied varieties by applying $60 \mathrm{~kg} \mathrm{~N} / \mathrm{fed}$ at tillering. However N-uptake by wheat variety Sids7 pronounced Giza 168 by $19.41 \%$. Similar results were reported by Rahman et al (2002).

Table (5). Effect of $\mathrm{N}, \mathrm{K}$ and timing of $\mathrm{N}$ application on $\mathrm{N}$ uptake $(\mathrm{Kg} / \mathrm{fed})$ of Giza 168 and Sids 7 (The mean values over two seasons).

\begin{tabular}{|c|c|c|c|c|c|c|c|}
\hline \multirow{3}{*}{\multicolumn{2}{|c|}{ Treatments }} & \multicolumn{6}{|c|}{ N uptake } \\
\hline & & \multicolumn{2}{|c|}{ Tillering } & \multicolumn{2}{|c|}{ Booting } & \multicolumn{2}{|c|}{ Maturity } \\
\hline & & G168 & Sids7 & G168 & Sids7 & G168 & Sids7 \\
\hline \multicolumn{2}{|l|}{ N75 } & 17.6 & 20.5 & 31.2 & 36.24 & 51.9 & 57.3 \\
\hline \multicolumn{2}{|c|}{ N120 } & 33.5 & 38.7 & 50.7 & 61.58 & 57.5 & 86.5 \\
\hline \multicolumn{2}{|c|}{$+\%$} & +90.4 & +90.0 & +62.7 & +69.0 & 64.4 & 89.7 \\
\hline \multicolumn{2}{|l|}{ Ko } & 23.3 & 26.7 & 38.5 & 44.92 & 55.3 & 62.9 \\
\hline \multicolumn{2}{|l|}{$\mathrm{K} 50$} & 27.8 & 32.5 & 43.4 & 52.89 & 63.4 & 77.7 \\
\hline \multicolumn{2}{|l|}{$+\%$} & +19.4 & +21.7 & +12.7 & +17.7 & 28.3 & 41.5 \\
\hline \multicolumn{2}{|l|}{ Do } & 5.38 & 6.19 & 8.55 & 8.34 & 13.2 & 14.1 \\
\hline \multirow{6}{*}{$\begin{array}{c}\text { Increment } \\
\text { over Do }\end{array}$} & $\mathrm{D} 1$ & 216 & 220 & 267 & 295 & 569 & 657 \\
\hline & D2 & 281 & 283 & 322 & 364 & 577 & 692 \\
\hline & D3 & 348 & 352 & 365 & 618 & 653 & 691 \\
\hline & D4 & 406 & 417 & 407 & 512 & 682 & 738 \\
\hline & D5 & 463 & 484 & 442 & 608 & 699 & 748 \\
\hline & D6 & 507 & 511 & 471 & 641 & 698 & 764 \\
\hline
\end{tabular}




\section{- Phosphorus uptake:}

Table (6) indicated that increasing $\mathrm{N}$ up to $120 \mathrm{~kg} \mathrm{~N} / \mathrm{fed}$ increased $\mathrm{P}$ uptake by the studied wheat varieties at maturity stage $28.9 \%$ and $51.95 \%$ for the two studied varieties. Also P-uptake at maturity was increased 19.82 $\%$ and $20.0 \%$ for the two studied varieties by applying $50 \mathrm{~kg} \mathrm{~K} \mathrm{~K}_{2} \mathrm{O} / \mathrm{fed}$. The highest relative increments were 322.03 and $358.38 \%$ for the two studied varieties by applying $50 \mathrm{~kg} \mathrm{~N} / \mathrm{fed}$. at tillering stage. While P-uptake by wheat variety Sids7 pronounced Giza 168 by $11 \%$. These results supported by Shams El Din (1989)

Data revealed that P-uptake by wheat plants at tillering stage increased $74.68 \%$ and $72.38 \%$ for the two studied varieties by increased $\mathrm{N}$ from 75 to $120 \mathrm{~kg} \mathrm{~N} / \mathrm{fed}$. Also P-uptake at tillering stage increased 21.96 and $22.3 \%$ for the two studied varieties by applying $50 \mathrm{~kg} \mathrm{~K} 2 \mathrm{O} / \mathrm{fed}$. The highest relative increments were $519.2 \%$ and $487.03 \%$ for the two studied varieties by applying $60 \mathrm{~kg} \mathrm{~N} / \mathrm{fed}$. in tillering stage. These results were supported by El-Sherbieny et al (1999)

Table (6) showed that P-uptake by wheat plants at booting stage was increased $66.46 \%$ and $90.16 \%$ for the two studied varieties by increased N from 75 to $120 \mathrm{~kg} \mathrm{~N} / \mathrm{fed}$. Also P-uptake was increased $21.03 \%$ and $29.49 \%$ for the two studied varieties by applying $50 \mathrm{~kg} \mathrm{~K} \mathrm{~K}_{2} \mathrm{O} / \mathrm{fed}$. The highest relative increments were 483.7 and $576.13 \%$ for the two studied varieties by applying $60 \mathrm{~kg} \mathrm{~N} / \mathrm{fed}$. in tillering stage. However P-uptake by Sids7 pronounced Giza 168 by $32.65 \%$. These results were supported by Koreish et al (2004) and Amer (2009)

Table (6). Effect of $\mathrm{N}, \mathrm{K}$ and timing of $\mathrm{N}$ application on $\mathrm{P}(\mathrm{Kg} / \mathrm{fed})$ of Giza 168 and Sids 7 (The mean values over two seasons).

\begin{tabular}{|c|c|c|c|c|c|c|c|}
\hline \multirow{3}{*}{\multicolumn{2}{|c|}{ Treatments }} & \multicolumn{6}{|c|}{$P$ uptake } \\
\hline & & \multicolumn{2}{|c|}{ Tillering } & \multicolumn{2}{|c|}{ Booting } & \multicolumn{2}{|c|}{ Maturity } \\
\hline & & G 168 & Sids7 & G 168 & Sids7 & G 168 & Sids7 \\
\hline \multicolumn{2}{|l|}{ N75 } & 1.6 & 1.81 & 5.01 & 5.69 & 12.16 & 12.26 \\
\hline \multicolumn{2}{|l|}{ N120 } & 2.8 & 3.12 & 8.34 & 10.82 & 15.67 & 18.63 \\
\hline \multicolumn{2}{|l|}{$+\%$} & +74.68 & +72.38 & +66.46 & +90.16 & +28.90 & +51.95 \\
\hline \multicolumn{2}{|l|}{ Ko } & 1.98 & 2.22 & 6.04 & 7.19 & 12.66 & 14.04 \\
\hline \multicolumn{2}{|l|}{ K50 } & 2.42 & 2.72 & 7.31 & 9.31 & 15.17 & 16.85 \\
\hline \multicolumn{2}{|l|}{$+\%$} & +21.96 & +22.30 & +21.03 & +29.49 & +19.82 & +20.00 \\
\hline \multicolumn{2}{|l|}{ Do } & 0.47 & 0.54 & 1.41 & 1.51 & 3.54 & 3.46 \\
\hline \multirow{6}{*}{$\begin{array}{c}\text { Increment } \\
\text { over Do }\end{array}$} & D1 & 206.38 & 198.15 & 267.38 & 251.65 & 244.63 & 323.12 \\
\hline & D2 & 272.34 & 264.81 & 324.11 & 325.17 & 267.79 & 336.99 \\
\hline & D3 & 340.42 & 342.60 & 365.25 & 455.6 & 305.68 & 347.68 \\
\hline & D4 & 414.89 & 396.30 & 409.92 & 499.3 & 311.86 & 356.06 \\
\hline & D5 & 470.21 & 464.81 & 446.1 & 554.30 & 322.03 & 358.38 \\
\hline & D6 & 519.15 & 487.03 & 483.7 & 576.13 & 309.03 & 355.78 \\
\hline
\end{tabular}

\section{3-Potassium uptake:}

Table (7) pointed out that k-uptake by wheat yield was increased by about $35.32 \%$ and $39.03 \%$ for the two studied varieties, by increasing $\mathrm{N}$ from 75 to $120 \mathrm{~kg} / \mathrm{fed}$. Also K-uptake increased $15.68 \%$ and $26.82 \%$ for the 
Faizy, S. E. A. et al.

two studied varieties with applying $50 \mathrm{~kg} \mathrm{~K}$ O/fed. The highest increment was $247.39 \%$ for Giza 168 by adding $50 \mathrm{~kg} \mathrm{~N} / \mathrm{fed}$ and $234.62 \%$ for Sids 7 by applying $60 \mathrm{~kg} \mathrm{~N} / \mathrm{fed}$. at tillering stage. However K-uptake by wheat varieties. Sids7 pronounced Giza 168 by $3.23 \%$. These results were supported by El Yamany (1994) and El Sherbieny et al (1999).

Table (7) showed that k-uptake by wheat at tillering stage increased $64.5 \%$ and $61.86 \%$ for the two studied varieties by increasing $\mathrm{N}$ from 75 to $120 \mathrm{~kg} / \mathrm{fed}$. K-uptake increased by about $20.45 \% 21.41 \%$ for the two studied varieties by applying $50 \mathrm{~kg} \mathrm{~K} 2 \mathrm{O} / \mathrm{fed}$. The highest increments were $438.47 \%$ and $469.96 \%$ for the two studied varieties by applying $60 \mathrm{~kg} \mathrm{~N} / \mathrm{fed}$. at tillering . K-uptake by wheat plants at booting stage was increased $73.41 \%$ and $69.15 \%$ for the two studied varieties by increasing $\mathrm{N}$ from 75 to $120 \mathrm{~kg} / \mathrm{fed}$. Also K-uptake increased $30.52 \%$ and $27.8 \%$ for the two studied varieties by applying $50 \mathrm{~kg} \mathrm{~K}$ O/fed. However K-uptake by Sids7 pronounced Giza 168 by $19.64 \%$. These results were supported by El Beyali et al. (2000).

Table (7). Effect of $\mathrm{N}, \mathrm{K}$ and timing of $\mathrm{N}$ application on $\mathrm{K}$ uptake $(\mathrm{Kg} / \mathrm{fed})$ of Giza 168 and Sids 7 (The mean values over two seasons).

\begin{tabular}{|c|c|c|c|c|c|c|c|}
\hline \multirow{3}{*}{\multicolumn{2}{|c|}{ Treatments }} & \multicolumn{6}{|c|}{ K uptake } \\
\hline & & \multicolumn{2}{|c|}{ Tillering } & \multicolumn{2}{|c|}{ Booting } & \multicolumn{2}{|c|}{ Maturity } \\
\hline & & G 168 & Sids7 & G 168 & Sids7 & G 168 & Sids7 \\
\hline \multicolumn{2}{|c|}{ N75 } & 16.99 & 19.43 & 28.12 & 34.2 & 54.43 & 55.32 \\
\hline \multicolumn{2}{|c|}{ N120 } & 27.96 & 31.45 & 48.76 & 57.80 & 73.66 & 76.91 \\
\hline \multicolumn{2}{|c|}{$+\%$} & +64.6 & +61.9 & +73.4 & +69.2 & +35.3 & +39.0 \\
\hline \multicolumn{2}{|c|}{ Ko } & 20.39 & 22.98 & 33.35 & 40.4 & 59.39 & 58.30 \\
\hline \multicolumn{2}{|c|}{$\mathrm{K} 50$} & 24.56 & 27.90 & 43.53 & 51.6 & 68.70 & 73.93 \\
\hline \multicolumn{2}{|c|}{$+\%$} & +20.5 & +21.4 & +30.5 & +27.8 & +15.5 & +26.8 \\
\hline \multicolumn{2}{|c|}{ Do } & 5.38 & 6.18 & 9.22 & 9.82 & 19.52 & 20.62 \\
\hline \multirow{6}{*}{$\begin{array}{c}\text { Increment } \\
\text { over Do }\end{array}$} & D1 & 179.93 & 154.41 & 234.59 & 217. & 199.9 & 204.4 \\
\hline & D2 & 240.33 & 233.82 & 283.84 & 275 & 209.58 & 211.2 \\
\hline & D3 & 296.84 & 292.88 & 317.68 & 372 & 224.89 & 218.6 \\
\hline & D4 & 345.72 & 237.06 & 353.1 & 435. & 242.78 & 225. \\
\hline & D5 & 406.69 & 401.29 & 381 & 468.0 & 247.39 & 229.8 \\
\hline & D6 & 438.47 & 424.59 & 404.89 & 470 & 244.42 & 234.6 \\
\hline
\end{tabular}

\section{- N-recovery:}

Table (8) pointed out that $\mathrm{N}$-recovery at tillering stage increased 91.95 $\%$ and $77.31 \%$ for the two studied varieties by increasing $\mathrm{N}$ from75 to 120 $\mathrm{kg} / \mathrm{fed}$. Also $\mathrm{N}$ recovery by the two wheat varieties increased $27.99 \%$ and $24.64 \%$ for the two studied varieties by applying $50 \mathrm{~kg} \mathrm{~K} \mathrm{~K}_{2} \mathrm{O} / \mathrm{fed}$. However the $\mathrm{N}$ recovery was decreased by increasing $\mathrm{N}$ doses at tillering stage, where recorded highest value under D1. These results supported by Nankova (1985)

Data showed that $\mathrm{N}$-recovery of wheat varieties at booting stage increased $32.98 \%$ and 33.28 for the two studied varieties by increasing $\mathrm{N}$ up to 120 $\mathrm{kg} / \mathrm{fed}$. Also, N-recovery at booting stage increased $17.7 \%$ and $26.15 \%$ for the two studied varieties by applying $50 \mathrm{~kg} \mathrm{~K} \mathrm{~K}_{2} \mathrm{O} / \mathrm{fed}$. However N-recovery of 
Sids7 pronounced Giza 168by $26.43 \%$. These results were supported by Karlen and Sadler (1990).

Table (8) indicated that N-recovery of wheat variety Giza 168 at maturity stage was decreased by $(-13.28 \%)$ with increasing $N$ to $120 \mathrm{~kg} / \mathrm{fed}$, while N-recovery of Sids 7 was increased by $12.69 \%$ with increasing $N$ to 120 $\mathrm{kg} / \mathrm{fed}$., N-recovery of wheat variety at maturity was increased $21.92 \%$ and $26.92 \%$ for the two studied varieties with applying $50 \mathrm{~kg} \mathrm{~K} \mathrm{~K}_{2} \mathrm{O} / \mathrm{fed}$. The highest N-recovery was recorded under D5 (50 kg N/fed) for Giza 168 and D6 $(60 \mathrm{~kg} \mathrm{~N} / \mathrm{fed}$.) at tillering for Sids7, N-recovery of wheat variety Sids7 (56.9 $\%)$ pronounced Giza $168(47.97 \%)$ by $18.69 \%$. These results were supported by Blankenau et al. (2000).and Amer (2009).

Table (8). Effect of $\mathrm{N}, \mathrm{K}$ and timing of $\mathrm{N}$ application on the recovery percentage of $N$ by Giza 168 and Sids 7 at different growth stages (the values over mean two seasons).

\begin{tabular}{|c|c|c|c|c|c|c|c|}
\hline \multicolumn{2}{|c|}{ Treatments } & \multicolumn{3}{|c|}{ Giza 168 } & \multicolumn{3}{c|}{ Sids 7 } \\
\cline { 2 - 8 } & Tillering & Booting & Maturity & Tillering & Booting & Maturity \\
\hline \multirow{2}{*}{ N-levels } & 75 & 26.97 & 35.69 & 51.35 & 33.62 & 45.07 & 53.50 \\
\cline { 2 - 8 } & 120 & 51.77 & 47.46 & 44.35 & 59.55 & 60.07 & 60.29 \\
\hline $\begin{array}{c}\text { Relative } \\
\text { variation } \\
\%\end{array}$ & $\%$ & +91.95 & +33 & -13.28 & +77.1 & +33.3 & +12.69 \\
\hline \multirow{2}{*}{\begin{tabular}{c} 
K-levels \\
\cline { 2 - 8 }
\end{tabular}} & 0 & 34.54 & 38.19 & 43.21 & 41.48 & 46.49 & 50.14 \\
\hline $\begin{array}{c}\text { Relative } \\
\text { variation\% }\end{array}$ & $\%$ & +27.99 & +17.7 & +21.9 & +24.6 & +26.2 & +26.9 \\
\hline \multirow{4}{*}{\begin{tabular}{c} 
N-Doses \\
\cline { 2 - 8 }
\end{tabular}} & D1 & 54.83 & 36.47 & 39.11 & 67.5 & 41.78 & 51.68 \\
\cline { 2 - 8 } & D3 & 37.34 & 39.05 & 42.82 & 43.35 & 44.69 & 52.69 \\
\cline { 2 - 8 } & D4 & 35.94 & 41.66 & 47.79 & 42.89 & 54.57 & 54.92 \\
\cline { 2 - 8 } & D5 & 36.16 & 44.43 & 52.60 & 42.33 & 57.07 & 58.70 \\
\cline { 2 - 8 } & D6 & 34.76 & 44.92 & 52.69 & 42.05 & 60.24 & 59.69 \\
\hline
\end{tabular}

\section{$\mathrm{N}$-use efficiency of the two wheat varieties:}

Table (9) revealed that N-use efficiency (NUE) of wheat variety Giza 168 decreased about $28.23 \%$ with increasing $N$ from 75 to $120 \mathrm{~kg} \mathrm{~N} / \mathrm{fed}$. while NUE of wheat variety Sids 7 increased by about $3.93 \%$ with increasing $\mathrm{N}$ from 75 to $\mathrm{N} 120 \mathrm{~kg} / \mathrm{fed}$. Also, NUE was increased by $18.21 \%$ and $19.24 \%$ for the two studied varieties by applying $50 \mathrm{~kg} \mathrm{K2O/fed.} \mathrm{The} \mathrm{highest} \mathrm{mean}$ value of NUE (23.04 kg grain $/ \mathrm{kg} \mathrm{N}$ ) was recorded under D5 $(50 \mathrm{~kg} \mathrm{~N} / \mathrm{fed})$ for wheat variety Giza 168, and $(27.1 \mathrm{~kg}$ grain $/ \mathrm{Kg}$ ) and under D6 ( $60 \mathrm{~kg} \mathrm{~N} / \mathrm{fed}$ ) at tillering for wheat variety Sids7. However, NUE of wheat variety Sids7 pronounced Giza 168 by $20.39 \%$. These results supported by Amer (2009). 
Faizy, S. E. A. et al.

Table (9). Nitrogen use efficiency of Giza 168 and Sids 7 as effected by $\mathrm{N}, \mathrm{K}$ and timing of $\mathrm{N}$ application (the mean values over two seasons)

\begin{tabular}{|c|c|c|c|}
\hline \multicolumn{2}{|c|}{ Treatments } & Giza 168 & Sids 7 \\
\hline \multirow{2}{*}{ N-levels } & $\mathbf{7 5}$ & 23.59 & 23.91 \\
\cline { 2 - 4 } & $\mathbf{1 2 0}$ & 16.91 & 24.85 \\
\hline \multicolumn{2}{|c|}{ Relative variation \% } & -28.23 & +3.93 \\
\hline \multirow{2}{*}{ K-levels } & $\mathbf{0}$ & 18.56 & 22.24 \\
\cline { 2 - 4 } & $\mathbf{5 0}$ & 21.94 & 26.52 \\
\hline \multirow{2}{*}{ Relative variation \% } & +18.21 & +19.24 \\
\hline \multirow{4}{*}{ N-Doses } & $\mathbf{D}_{1}$ & 14.69 & 20.93 \\
\cline { 2 - 4 } & $\mathbf{D}_{2}$ & 16.87 & 22.62 \\
\cline { 2 - 4 } & $\mathbf{D}_{3}$ & 21.39 & 23.86 \\
\cline { 2 - 4 } & $\mathbf{D}_{4}$ & 22.65 & 25.14 \\
\cline { 2 - 4 } & $\mathbf{D}_{5}$ & 23.04 & 26.0 \\
\cline { 2 - 4 } & $\mathbf{D}_{6}$ & 22.86 & 27.1 \\
\hline
\end{tabular}

-The crude protein content of wheat:

Data in Table (10) pointed that the crude protein content in grains of the two wheat varieties were increased by about $12.47 \%$ and $16.2 \%$ by increasing $\mathrm{N}$ from 75 to $120 \mathrm{~kg} / \mathrm{fed}$. and was increased by 5.48 and $7.06 \%$ by applying $50 \mathrm{~kg} \mathrm{~K} 2 \mathrm{O} / \mathrm{fed}$. These results supported by Amer (2009).

Table (10). The crude protein content (\%) in grains of two wheat varieties Giza168 and Sids7 (the mean values over two seasons).

\begin{tabular}{|c|c|c|c|}
\hline \multicolumn{2}{|c|}{ Treatments } & Giza 168 & Sids 7 \\
\hline \multirow{2}{*}{ N-levels } & $\mathbf{7 5}$ & 11.47 & 11.25 \\
\cline { 2 - 4 } & $\mathbf{1 2 0}$ & 12.90 & 13.08 \\
\hline Relative variation \% & $\%$ & +12.47 & +16.27 \\
\hline \multirow{2}{*}{ K-levels } & $\mathbf{0}$ & 11.86 & 11.75 \\
\cline { 2 - 4 } & $\mathbf{5 0}$ & 12.51 & 12.58 \\
\hline Relative variation \% & $\%$ & +5.48 & +7.06 \\
\hline \multirow{5}{*}{ N-Doses } & $\mathbf{D}_{\mathbf{0}}$ & 6.99 & 7.49 \\
\cline { 2 - 4 } & $\mathbf{D}_{1}$ & 12.39 & 12.37 \\
\cline { 2 - 4 } & $\mathbf{D}_{\mathbf{2}}$ & 12.32 & 12.28 \\
\cline { 2 - 4 } & $\mathbf{D}_{3}$ & 12.15 & 12.15 \\
\cline { 2 - 4 } & $\mathbf{D}_{\mathbf{4}}$ & 12.1 & 12.13 \\
\cline { 2 - 4 } & $\mathbf{D}_{5}$ & 12.07 & 12.01 \\
\cline { 2 - 4 } & $\mathbf{D}_{6}$ & 12.05 & 12.03 \\
\hline
\end{tabular}




\section{Thus it can be concluded that}

It is recommended to apply $120 \mathrm{~kg} \mathrm{~N} / \mathrm{fed}$. as $24,60,18$ and 18 at planting, tillering, booting and milking stages, respectively as well as applications of $50 \mathrm{~kg} \mathrm{~K} 2 \mathrm{O} / \mathrm{fed}$. and $22 \mathrm{~kg} \mathrm{P}_{2} \mathrm{O}_{5} / \mathrm{fed}$. before planting. to obtain the maximum values of $\mathrm{N}$-use efficienency, $\mathrm{N}$-recovery, NPK-uptake, crude protein content \% and yield for the studied wheat varieties Giza 168 and Sids7 under North Middle Delta conditions.

\section{REFERENCES}

A.O.A.C. (1980). "Association of official Agriculture chemists". (Official methods of analysis) , 13th Ed., Washington, D.C.

Adjetey.J.A;P.G.E. Searle and L.C. Campbell (2001). Rate and timing of nitrogen fertilizer applications on wheat grown under dry land and supplementary irrigation. South-African-J. of plant and soil, 18:1, 15-20.

Amer, M.M.A (2009). Response of Wheat Yield to Fertilization by Nitrogen, Potassium and Biofertilizers in Salt Affected Soils. Ph. D Thesis; Soils, Fac Agric. Kafr El - Sheikh Univ., Egypt .

Blankenau -K; H. Kuhlmann and H.W. OLFS (2000). Effect of increasing rates of $15 \mathrm{~N}$ - Labelled fertilizer on recovery of fertilizer $\mathrm{N}$ in plant and soil $\mathrm{N}$ pools in a pot experiment with winter wheat. J. of plant - nutrition and soil sci. 163:5, $475-480$.

Cochran, W.G. and, G. M. Cox (1960). "Experimental Designs", 2 ndded John welly, Newyork,: 293-316.

EI - Banna A. Y. A. ( 2000 ). Effect of seeding rates and PK fertilizer levels on grain yield and yield attributes of wheat under newly cultivated sandy soil conditions - Zagazig J . of Agric Res. 27 (5): 1161 - 1178 .

EL - Beyali , U.S. ;A.I.EL-Shafi and A.H.Ahmed (2000). Efficiency of soil and foliar application of potassium fertilizer on yield, yield components and some nutritional constituents of wheat grain on alluvial Bahtim soil .Egyption Journal of Applied Sciences. 16 : 297-313.

EI - Desokey, M. A.; A. Ghallab and E. A. Teama (2000). Efficient use and uptake of nitrogen for wheat yield in a clay soil in relation to split nitrogen application. Assiut- J. of-Agric. Sci. 31:5, 153-167.

EI - Desouqi, S. A. (2000). Effect of some nitrogen sources on growth and yield of wheat plants. Conf. International Colloquium for the optimization of plant nutrients, yield quality, the environment. 10th . Cairo (EGY). Apr. 8-13.

El - Sherbieny A. E.; K. G. Soliman and R. M. Ali (1999). Increasing the efficiency of nitrogen fertilizers in newly reclaimed sandy soil. Zagazig J. Agric. Res. $26: 38,895-906$.

El Kholy M. A. (2000). Response of wheat growth and yield to plant Density and methods of nitrogen and potassium fertilizers application Egypt. $\mathrm{J}$. Agron. .22, ( 1-18) .

El Yamany; S. M. (1994). Study of the Efficiency of some fertilizer treatments on wheat under Different irrigation conditions. ph. D Thesis, Fac. Agric. Kafr El - Sheikh, Tanta Univ., Egypt . 
Faizy, S. E. D. A.; T. M. El-Essawi; R. A. Ali and A. El-Shamly (1986). Spliting nitrogen and the effect of potassium fertilizer on grain yield of wheat, . J. Agric. Res. Tanta Univ., 12(4):1241-1247.

Forster, H. (1973). Effect of potassium and nitrogen supply to plants on yield components and yield formation of cereals. Landw. Forsch. 26:221227. (c. f. Mengel, and E. A. Kirkby (2001).

Genaidy, S. A. and M.A Hegazy (2001). Evaluation for effects of potassium fertilization from sulfate and chloride sources on some main field crops Egypt. J. Agric . Res.,79(2).

Gohar, A. T. (1954). The influence of Exchangeaple cations on physical properties of Egyptian soil M. Sc Thesis, Fac. of Agric. Cairo univ.

Hegab, M. T. (1994). Effect of nitrogen and potassium on wheat yield under wadi sidr conditions Annals of Agric. Sci.; Moshtohor, 32 (1) , 21-34.

Jackson, M.L. (1967)." Soil Chemical Analysis" prentice Hall of India Ltd New Delhi.

Kanani, R. E. E (1996), Effect of irrigation and fertilization on crop yield and nutrient uptake ; Thesis; ph. D.; Soil science; Fac . of Agric, Mansoura Univ.

Karlen.D.L and J.E. Sadler (1990), Nutrient accumulation rates for wheat in the southeastern coastal plain. Proceedings, International symposium on soil testing and plant Analysis, Aug. 14-18, 1989, Fresno, California; 18 ref.

Koch, K; and K. Mengel (1977). The effect of $\mathrm{K}$ on $\mathrm{N}$ fertilization by spring wheat during grain formation Agron. J. 69: 477 - 480.

Koreish. E. A., M. E. El-Fayoumy, H. M. Ramadan, and W. H. Mohamed (2004). Interaction Effect of organic and mineral fertilization on Falabean and wheat productivity in calcareous soils. Alex. J. Agric. Res. 49 (2) : 101 - 114.

Mengel; K and E. A. Kirkby (2001). "Principles of plant Nutrition". 5 th Edition KLUWER ACADEMIC publishers Dorotrecht / Boston / London.

Muhammad ; N.A.(2001). Curve analysis for evaluation of the response of some wheat varieties to different nitrogen fertilization levels. Journal of Agric .sci . Mansoura university 24 (4), 1559-1571..

Nankova.M (1985). Chemical composition of wheat plants depending on the developmental stage in relation to date and method of nitrogen fertilizer application. Rasteniev 'dnl -Nauki,, 22:8, 24-31.

Olsen, S.R.; C. V. Cale; F. S. Watenable and L. A. Dean (1954). Estimation of available phosphorus in soil by extraction with sodium bicarbonate U. S. Dept., Agric. Circ., 939.

Page, A. L. (1982) . Methods of soil analysis. Part 2: Chemical and microbiological properties (2nd ed.) Amer. Soc. Agron. In Soil Sci. Soc. Amr. Inc. Madison, Wisconsin, USA.

Piper, C. S. (1950). Soil and plant analysis. Inter science Publication. New York.

Rahman, M. A. ; M. A. Sufian; M. Saifuzzaman and J. Chikushi (2002). Nitrogen management in rice-wheat alternating cropping system and wheat genotype identification preferable to surface seeding condition. J.-of-the - Faculty-of Agric. Kyushu-Univ. 46:2,295-301. 
Shams El-Din, H. A. I. (1989). The efficiency of liquid ammonia and some solid nitrogenous fertilizers on wheat growth and yield. M. Sc. Thesis, Fac. Agric. Mansoura Univ., Egypt.

Sing.R.N and R.K.Pathak (2003) Effect of potassium and magnesium on yield, their uptake and quality characteristics of wheat (Triticum aestivum). Journal of the Indian society of soil science, 2, 181-185.

Staggenborg.S.A; D.A.whitney; D.L.Fjelland J.P. (2003). Shroyer seeding and nitrogen rates required to optimize winter wheat yields fellowing grain sorghum and soybean.Agronomy-Journal., 95:2, 253-259.

Wagan M. R; F. C . Oad and K. S. Nenwani ( 2002 ). Wheat growth and yield contributing characters under various sources and schedules of nitrogen fertilizer Pakistan - J. - of - Applied - sciences. 2:11, 1013 1015.

Warraich, E. A.; Nazik-Ahmed; S. M. A. Basra and Irfan-Afzal (2002). Effect of nitrogen on source-sink relationship in wheat. International- J. ofAgric.-and Biology. 4:2, 300-302.

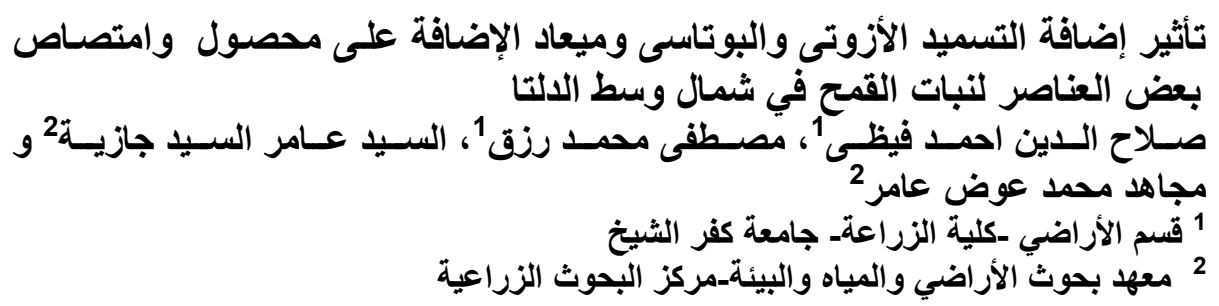

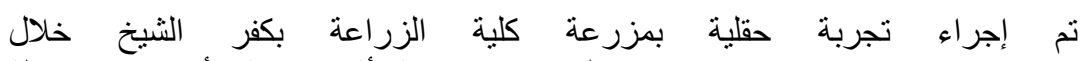

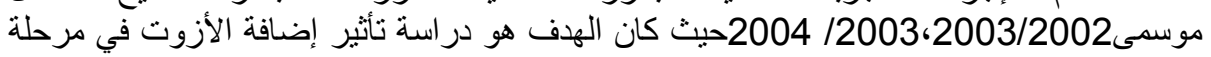

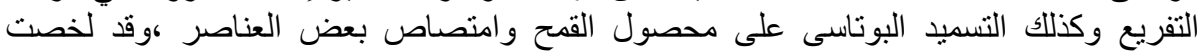

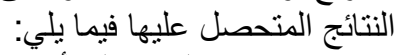

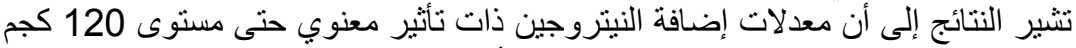

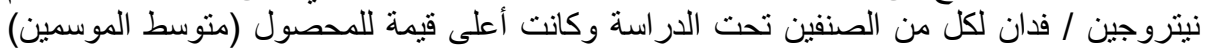

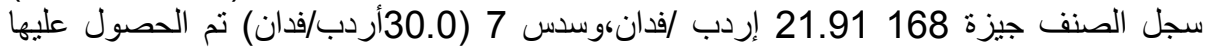
بإضافة 120كجم نبتروجين للفدان مقسمة كالتالي(24 : 60: 18:18) كجم نيتروجين للفدان الثان أنثاء

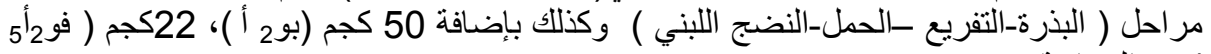

توضح النتائج أن معدلات إضافة النيتروجين لها تأثير معنوي على قش القمح حتى معدل

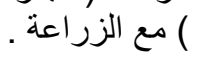

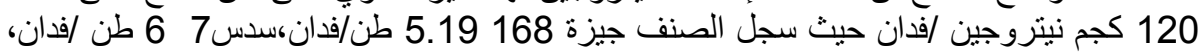

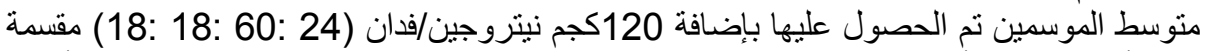

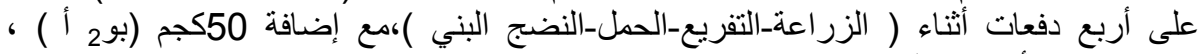

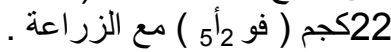

تثير النتائج إلى زيادة المادة الجيادة الجافة في مرحلة التفريع والحمل و النضج لكل من الصنفين

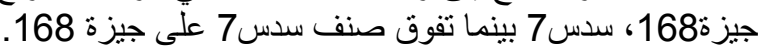

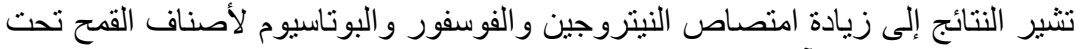

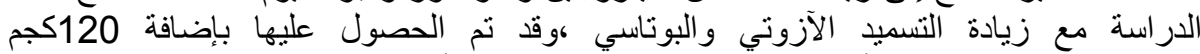

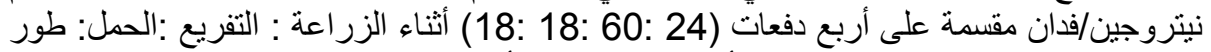
النضج اللبني، مع إضافة 50كجم (بو2 أ )، 22 كجم (فو 2أ5). 
Faizy, S. E. A. et al.

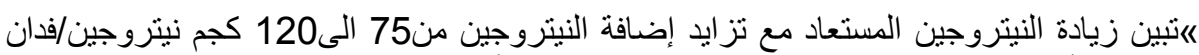

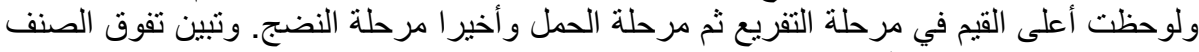

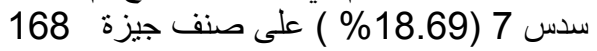

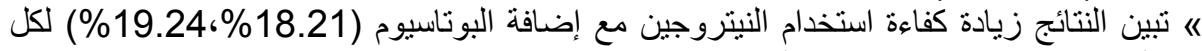

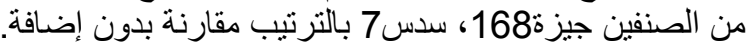

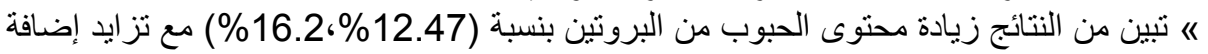

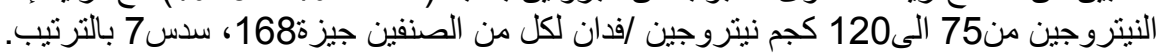

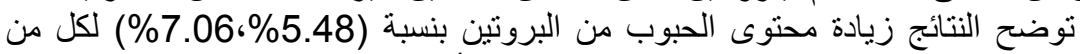

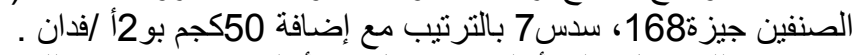

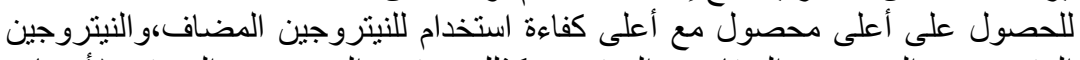

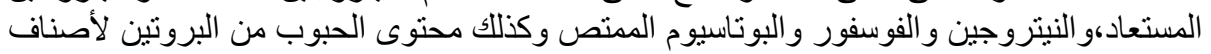

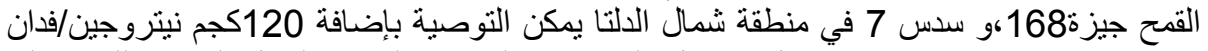

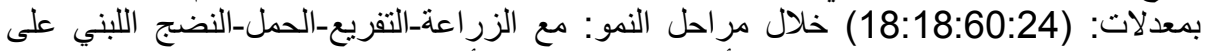

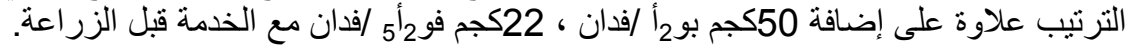

كلية الزراعة - جامعة المنصورة قام بتحكيم البحث مركز البحوث الزراعية أ.د / أحمد عبد الجدم القادر طه أ.د / أد / محمد مصطفى رجب القبر طب 